\title{
Analysis of Consequences and Ordinances of Revocation in Khula and Mubarat Divorce
}

\author{
Sayed Mohammad Shahab Mirshahzadeh ${ }^{1} \&$ Mohammad Hossein Karimi ${ }^{1}$ \\ ${ }^{1}$ Department of Law, Meybod Branch, Islamic Azad University, Meybod, Iran \\ Correspondence: Sayed Mohammad Shahab Mirshahzadeh, Department of Law, Meybod Branch, Islamic Azad \\ University, Meybod, Iran.
}

Received: May 15, 2016 Accepted: June 2, 2016 Online Published: June 29, 2016

doi:10.5539/jpl.v9n5p242 URL: http://dx.doi.org/10.5539/jpl.v9n5p242

\begin{abstract}
The divorce means dissolution of marriage permanent that has been done after performing divorce and since then is interrupted conjugal relationship between husband and wife, however, according to the type of divorce resulting from their work will be different. One of iqaat in Jurisprudence accepted by the man to see his wife at the time of iddah and also return women to we pay in order to possible to return the men to marriage in Khula and Mubarat divorce. In some cases challenges returning to philosophy of divorce and a kind of defeating the purpose will be done that the opportunity does not give the men. And thus the nature of divorce is irrevocable and complete separation between men and women is created. Given the importance of returning issue, this research examines the effects of works and judgments of return on Khula and Mubarat divorce. After reviewing, finally, it was concluded that there is not difference between return and its effect in Khula and Mubarat divorce and the only difference is in the nature of these two divorces. So it is necessary that this issue comprehensively reflected in the law books.
\end{abstract}

Keywords: return, Khula, Mubarat, irrevocable divorce

\section{Introduction}

One of the current problems of our society is divorce and causes many social, cultural and so on problems. Therefore it is necessary to pay the subject of divorce with the hope that it will be of little help in solving the problem, however, the divorce is legal only solvent which God did not like it and one of legal rights and lawful couples is considered. This right is important subject that shed the traditions narrated from the throne of God shakes the place. One of iqaat which is located in Shiite Jurisprudence accepted, return the man to his wife at the time of iddah and also return the wife to pay in order to allow return man to marriage in Khula and Mubarat divorce ${ }^{1}$ For various reasons has Verses see proof of this can be said without any problem jurisprudents have accepted this subject. Also the jurists said and civil law as a result, it has put in mind. Revocable divorce where there is a possibility of return man is also in Khula and Mubarat divorce after her return to ransom, or dowry man immediately (with urgency) could return to his marriage ${ }^{2}$. Now this question is why and why jurists attempt to separate the couple have done and finally reached their goal is to provide an opportunity for women to be able to return to what forgive and men also have the possibility to return to the divorce? The initial response to this question is that it is the sacred religion of Islam for the strength of the family and avoid the divorce of things to consider divorce deal that divorce does not occur to the extent possible and if the divorce occurred, then make the necessary space to be able to re-experience the couple shared living space except this general rule, however, is the possibility of return for men or for women, in some cases challenges returning to philosophy of divorce and a kind of defeating the purpose will be done that the opportunity does not give the men and thus the nature of divorce is irrevocable and complete separation between men and women is created ${ }^{3}$. The purpose of this research is to find the works of return in Khula and Mubarat divorce and comparison of these two together is due to the

\footnotetext{
${ }^{1}$ Katouzian, Nasser, 2008. Current civil law legal order, Tehran, Mizan Publication.p358.

Emami, Hassan, 1998. Civil Rights: Tehran, Islamic bookstore.Pp 277 and 177.

${ }^{2}$ Katouzian, Nasser, 2006, introductory courses of civil rights, legal actions: Contract - iqaa. Tenth Edition, Tehran: Enteshar Publication Co. P 383 .

${ }^{3}$ Mohaghegh Damad, Seyed Mostafa 2003, legal study of family law, marriage and its dissolution, printing 10, Tehran: Publishing Center of Islamic Sciences. pp. 366 and 365
} 
foregoing, the question arises: In case of return in Khula and Mubarat divorce what works and rules are applied? Also what is the difference between the return on Khula divorce and return on Mubarat divorce?

\section{Literal and Technical Meaning of Return}

Return is a legal act: this means that it works and develop the will and should be the subject of purpose. For example, if the donor can return the gift that will have a healthy determination ${ }^{4}$. It also encourages his extradition to dissolve the contract and return the donation must be made subject. Return should not be considered as an inevitable effect of no current, although that would normally be used for the return. Yet relying on «being voluntary» return, especially in a place that clearly do not have significance and purpose of the action is a different matter and return Donor implicitly it is concluded. For example, in the case that after the submission donation Donor sells it to others. While return is part of Iqaat, if that is so esoteric figure will be notified and plans. Apart from the fact that for some people in the revocable divorce, the husband has the right to return, also have the rights and obligations of the parties with rights and duties irrevocable divorce is different. For example, if a revocable divorce, wife or husband dies, the wife is entitled to the inheritance and alimony. Men are not allowed until the time of iddah has not ended, divorced from the location of residences, ie outside the home. Men and women outside of marriage-bound and not in a revocable divorce at this time if they commit fornication, adultery is adultery them ${ }^{5}$.

\subsection{Effects of Return in Khula Divorce}

In case of return in Khula divorce after divorce, men can not realize this at the time of iddah will return to his wife; but she can to her husband return at the time of iddah the ransom payment and to withdraw it, however, is unhappy man. In this case, couples can return to his wife ${ }^{6}$.Legal documentation is permit wife's return, aside from the consensus, the narratives which referred to a few of them: Quoted from Mohammad ibn Esmaeil ibn Bazie: "And that she wants to respond to what took them and be his wife did.» ${ }^{7}$ ibn Sanan Al-Marvi Fi Al-mahki An Tafsire Ali ibn Ebrahim «Irreversible for the husband on the dysfunctional, and not on the game, but it seems to women, it contained what was taken from them; .... ${ }^{8}$. That permit of women return is subject to possible return true man or not, is different. So in the first, if not the impossibility of return man as the woman who is divorced for three time, women's return is not correct. Also in being correct of women return if the husband is aware of it or not, is different. The first quote, in the absence of her husband to return to ransom by the end of the number, return the woman is void " ${ }^{9}$ Even if it is clear from this (return to pay his wife) know not, return the wife to pay will be invalidated. Apart from the above, return must be such that the husband have the ability to return to the marriage. This famous quote has been attributed. So if Khula divorce is located, is irrevocable nature (such as divorce menopausal, none his income, absolute divorce on the third and minor Therefore, the husband divorces in this way will have the right to return ${ }^{10}$, With this quote in return wife will be void. Also, if after Khula divorce, husband with wife divorced sister marries another wife does not have the right to return to munificence; because it is impossible to return the missing husband. Because if the parties agreed to consider giving husband was against Khula divorce; in other words, which is the purpose of this fiscal against the wife to the husband, husband also gives her divorce irrevocable, if the wife would return to pay and withdraw it, but the husband fails to return the marriage would be contrary to the will of the parties in common and aside from this, return wife to pay in the event of losses husband and the loss caused no harm rule will be canceled. Regardless of the arguments above, Sharia and law decreed that wife when he could return to redeem that the husband also have the ability to return to the marriage and return wife's otherwise known, is not effective and this important reason for the ineffectiveness of return wife when a man fails to return the marriage. Imam Khomeini says in this regard: that permit the return of women in munificence, subject to the possibility of her husband's return after his return, but if not possible, such as women and divorced three times, or if the women who has not iddah such as menopause and none his income of value, the waiver does not have the right to return but return inaccuracies woman assuming it does not know the man until the expiration of the return is unlikely. So if the woman herself and her husband know it does not return until the iddah be expired is not a work for the return of women." Imam Khomeini, believes that the return wife to pay, however, irrevocable and revocable divorce the husband disappears and could return during the iddah to wife.

\footnotetext{
${ }^{4}$ Emami, Hassan, 1998. Civil Rights: Tehran, Islamic bookstore.Pp 277 and 177.p404.

${ }^{5}$ Katouzian, Nasser, Family Law, Civil Rights Foundation. 2003.p134.

${ }^{6}$ Najafi, Mohammad Hassan 1981, Javaher al-Kalam fi Sharhe Sharaye al-Islam, vol. 7, Beirut: Dar al-Ahya al-Taras al-Arabi. P $62-63$.

${ }^{7}$ Hurr Ameli, Mohammad ibn Hassan, Vasael Al-Shiaa, Qom, Al al-Bayt Institute, 1409 AH.P22-286.

${ }^{8}$ ibid: p. 293

${ }^{9}$ Najafi, Mohammad Hassan 1981, Javaher al-Kalam fi Sharhe Sharaye al-Islam, vol. 7, Beirut: Dar al-Ahya al-Taras al-Arabi. P $63-65$.

${ }^{10}$ ibid, p. 64
} 


\subsection{The Effects of the Atonement in Kuala and Murat Divorce and to Return Wife}

The well-known saying that divorce is independent and redemption Dai disarmament and sets it on its creation, redemption if the direction is wrong directions, It is not like that tax or a third party have to pay it yourself divorce is simply a fact, and the nature of your home, i.e. when it is revocable at the time of iddah husband can divorce his return, and when it is irrevocable such as divorce or post-menopausal women or divorced before approaching the third time, the husband could divorce his return. But when the divorce is void caused by the absence of a requirement, not the owner's husband ransom and return the effect will be canceled. If the woman's property, with ignorance to make this sacrifice, it is known that women turn to their husbands sponsor of like or price, It is clear that the ransom money placed because it has the potential to be a ransom, but in effect it is owned by a non-owner husband is not. Because of these differences, it seems positively will not claim to invalidate the redemption with other items on top of it. The legal nature of Khula divorce and Mubarat not only is interesting in theory, in practice there are also important benefits that are among them: If the relationship between the ransom and divorce is like the relationship between the change in trading ransom prevent the occurrence of divorce is invalid because of causality between the two is dictated by the realization of one of them without the other so if someone else is redeemed or abandon the husband is not like divorce Instead, they will also be located. On the contrary, if the divorce is regarded as an independent Rhythmic redemption invalidity does not affect the access of divorce and such is the case because of lack of agreement on the seal or conditions of the contract impossible or opposition to the law is null and void. Legal nature of the divorce pursuant to paragraph 3 of Article $1145 \mathrm{BC}$ "Khula divorce and Mubarat as long as the woman did not return for an "irrevocable legal nature of these divorces are, so to get to know the differences between various stage shows: 1- Divorce is located but women still did not return to change: at this point the divorce is irrevocable and may not return to marry and she does not have the right to alimony from her husband and the husband dies not inherit from him. 2- As soon as the woman rather than return the divorce rediscovers his original nature, therefore, if the divorce is revocable by its nature it will create the possibility of return to marriage and the woman will win the right to alimony and inheritance.

\subsection{Condition of the Right to Return to Ransom in Khula Divorce}

If during the iddah possible to return to the redemption provision, or condition of return to marriage in return iddah on woman's honor redeemed in iddah, because disarmament is a requirement of the contract, Khula divorce does not invalidate. It should be noted that if the wife would return to pay and withdraw it, but marriage husband fails to return marriage, it would be incompatible with the common will of the parties and aside from this, return wife to pay in the event of losses husband and the loss caused no harm rule will be canceled. Regardless of the arguments above, Sharia and law decreed that wife when he could return to redeem that the husband also have the ability to return to marriage and otherwise return of wife is not known effective. This important reason to return wife quail when a man fails to return the marriage. ${ }^{11}$

\subsection{Unwilling to Fda'}

Quoting from late Ayatollah Bahjat: "If your husband or any other man refused to give his ransom, divorce is not accepted and has reluctantly works. If the man has to pay ransom for the woman in front of woman's rights, including the rights obligatory such as alimony or other rights necessary to prevent such a close associate and confidant of Fda' not reluctantly, Although Muharram is not as reluctant; to the contrary intention for the purpose of duty abandonment. If a man divorces his wife and the woman reluctantly munificence the ransom was not revocable divorce and could return to his wife.

\subsection{Inaccuracies Disarmament without Hate}

Ayatollah Bahjat says: "If men and women are not averse to exist and disarm, if not properly stabilized and husband owns disarmament is not paid, so in this case the revocable divorce is pronounced the word in case of divorce or downright as passed, or else it is irrevocable or revoked or its location as in the past, and the apparent lack of nullity is pronounced divorce "(ibid.). Khula divorce is based on two pillars, one of the two hate and disdain of a wife to her husband, so that the durable life difficult for him or both and causes to sin and disobey and disregard for legal obligations and human emotions another on ransom. So no reluctantly dropped the ransom is not possible disarmament. ${ }^{12}$

\subsection{Bad Bearing in Case of Committing a Prostitute}

In the words of the late Ayatollah Bahjat: "If the woman was a prostitute bad man can walk towards it and $\mathrm{He}$

\footnotetext{
${ }^{11} \mathrm{http}: / /$ www.vekalat.org/public.php?cat= 2 \& newsnum $=2119880$ )

${ }^{12} \mathrm{http}: / /$ vekalat gachsaran.persianblog.ir/post/8
} 
will give the ransom him Khula divorce; if the prostitute is a woman certainly proven his intellect was tantamount to adultery and there is also the possibility that the verdict disobedience and likely all the other sins; and precaution discovered validity of hate prostitute is a woman, like others disarmament. Non-observance of women's rights and should be allowed, such as alimony and seem so precaution. And the muscles to waste Almosama stamp that is given to him, if not to harm ${ }^{13}$

\subsection{Return Rules in Munificence}

Failure to return to puncture during the iddah of caution. If there is no possibility of return in Khula divorce, the legal and rational iddah ended by that time, although without the knowledge of the likely return coincided with munificence is valid because it is a way of credit, in case of return in munificence, apparently ruling is revocable divorce. Such as alimony and inheritance, and no marriage license attached and Khameseh, to the contrary, we return to the irrevocable judgment on all the above, is fixed. After marriage optional, although it may be prudent not to return munificence return on disarmament to be irrevocable divorce and return to disarmament is optional. Return to some of the ransom, the ransom is tantamount to the total return, ie if the woman paid the man $\$ 10$ million as ransom until Khula divorce to take place, if the woman to tell a man that 2 million of the amount of return, such as the return of the whole property has been redeemed. Show up lack of a revocable divorce does happen to disarm in return for Fda' woman, divorce in exchange for disarmament to be, disarmament is about to be married but divorced revocable, and otherwise it is irrevocable, ie, remain and return Baynunah not place Although precaution to appropriate precautions is limited. In other words, analysis can be mutually agreed, saying: the foundation of the couple that is equal to the redemption Khula divorce or Mubarat, if a woman instead of a man's return and marriage have the ability to return to return to redemption only if it is possible for a man to marry a return is possible, for the purpose has been to the benefit that a woman brings to her husband, he had his irrevocable divorce a woman if she could change and take advantage of irrevocable divorce benefit. The result of this analysis is incompatible with the provisions of the contract is concluded if a woman does not have the iddah or return instead to be done so that there is no possibility for man to become aware of it and the right to return to marriage. Women return is ineffective but when man at the time of iddah create an obstacle to return to marriage that this prevents a woman's right to return does not eliminate ${ }^{14}$.

\subsection{The Failure to Achieve Disarmament after Divorce}

After the man refused to disarm in exchange for ransom wife does not divorce unless the woman ransom return and re marriage between them. By doing it, parity of them proven and is valid. So after being deposed for not return unless she return to the munificence redemption ${ }^{15}$.

\subsection{Please Divorce against Paying Money}

When the wife asked the husband to do which he received in exchange for taxes on three divorces, ie if to say: «Divorced me three thousand» and wife of Shiite, the predicate of his religion is legitimate if permeation is the divorce between the two return, however, even in one versus one third total disarmament correct a thousand, is not free from reflection; revocable or Irrevocable a divorce correct way, not round one instead of one third in cum inaccuracies disarmament in total a thousand, and make sure the two possibilities, return the license in return praised the munificence woman is said about it. And also [is] if to say: «Divorced me three thousand», if more than one divorce are left, what is scientist what a fool. And if the remaining two are divorced, after a divorce, which like Plea se divorce for survival is possible unless the quality of distribution. And if divorce twice, the probability distribution to two thirds, is vertical. And if the mistakes and ignorance of the rule, intended to non-Shiite religion's unity, not far discovery by going a result, a divorce is correct and disarmament, instead, he and a third of the total or all of it, if the article is Shiite, the same is autonomous. And if he had not meant the three return without permeation, according to his religion, then munificence is wrong with us, and with us is correct and dismantle the divorce is not revocable and irrevocable unless it is in the case.

\subsection{Invalidity of the Condition Return in the Disarmament and the Correct Ruling and the Lack of Correct of Divorce}

If the man his wife on condition of return Khula divorce which were provided to give false return is Khula divorce is also invalid. If she accepts the delayed acceptance of the return, divorce is not an obligatory precaution is located; therefore, if the woman agreed to delay the condition, redemption forgive and accept bets will be void and return Khula divorce was correct and if the effect does not occur. If the condition that the divorce Instead, they will get

\footnotetext{
${ }^{13}$ bahjat.ir-info@bahjat.ir

${ }^{14}$ Katouzian, Nasser, 2008. Current civil law legal order, Tehran, Mizan Publication. P290.

${ }^{15}$ bahjat.ir-info@bahjat.ir
} 
here is evacuated sentences (ibid.).

\section{Results}

As mentioned in Khula and Mubarat divorces to the credibility of the financial munificence of the real woman, such as the contract has two sides and will require mutual agreement. The derivative of the formula Mubarat divorce divorce may be said, as the woman say: Nuts me to give you that you Mubarat divorce, the husband answered him, saying: You are divorced, as well as on. If the word derives from Mubarat husband divorce, inevitably followed by the word "You are divorced, as well as on" be said, for example, if her husband says: As well as on your innocence, you must complete it in words, "You are divorced, as well as on", because the words derived from Mubarat not explicit in divorce. But in relation to the difference between the two divorce, the Ayatollah Mazaheri said in his teaching that he said between Khula divorce and Mubarat, there are three differences; that's mean, first he said that if there Khula divorce, Mubarat divorce there except that Tuesday is the difference between Khula divorce and Mubarat. He said first difference is that in Mubarat divorce should dislike is mutual, but in Khula divorce, the wife and the husband should not hate. In Khula divorce talked and said that Khula divorce, munificence of the wife wants. This is the difference between a revocable divorce in Mubarat divorce and Mubarat divorce and disarmament is in a revocable divorce the husband must give his munificence and dowry, but in Khula and Mubarat divorce, dowry them. Finally, the works of both Khula divorce and Mubarat are identical and have no significant difference, the only difference is in the nature of the Mubarat divorce with the explanation that they both hated each other but in Khula divorce is the only wife who is abomination. This is the difference between a revocable divorce and Mubarat divorce and disarmament is in a revocable divorce the husband should munificence and give a dowry, but in Khula and Mubarat divorce, dowry is the first alternative is also considering sharing these divorces is to have disdain.

\section{References}

Emami, H. (1999). Civil Rights: Tehran, Islamic bookstore.

Gorji, A. (2005). comparative family law. Tehran University Press.

http://vekalat gachsaran.persianblog.ir/post/8

http://www.vekalat.org/public.php?cat= 2 \& newsnum $=2119880$ )

Hurr Ameli, Mohammad ibn Hassan, Vasael Al-Shiaa, Qom, Al al-Bayt Institute, 1409 AH.

Katouzian, N. (1992). civil rights, family, co-published with the cooperation of Bahman Borna, third, 1992, vol. 1.

Katouzian, N. (2003). Family Law, Civil Rights Foundation.

Katouzian, N. (2006). introductory courses of civil rights, legal actions: Contract - iqaa (10th ed.). Tehran: Enteshar Publication Co.

Katouzian, N. (2008). Current civil law legal order. Tehran, Mizan Publication.

Mohaghegh Damad, Seyed Mostafa. (2003). legal study of family law, marriage and its dissolution, printing 10. Tehran: Publishing Center of Islamic Sciences.

Najafi, M. H. (1981). Javaher al-Kalam fi Sharhe Sharaye al-Islam (Vol. 7). Beirut: Dar al-Ahya al-Taras al-Arabi.

\section{Copyrights}

Copyright for this article is retained by the author(s), with first publication rights granted to the journal.

This is an open-access article distributed under the terms and conditions of the Creative Commons Attribution license (http://creativecommons.org/licenses/by/3.0/). 